\title{
Analysis of Labour Productivity and Determining the Parameters Which Affects it in Aluminium Formwork System
}

\author{
Rajnish Singh, Karthik Nagarajan, Raju Narwade
}

\begin{abstract}
The construction industry is considered to be one of the rapidly growing industries of India. So, to fulfil such a vast and constantly increasing construction demand the labour productivity is the key factor to maintain client satisfaction, attract investment, and contribute by helping the nation with its economic growth. Aluminium system formwork is one economical and technical approach to effectively maintain productivity of labours on site. Various research studies have been conducted to compare different types of formwork system and the advantages and disadvantages of each type of formwork system are examined in terms of cost, duration, quality etc. There is no standard procedure to put a number on the efficiency of the site labour, using aluminium formwork system in the industry. So, the primary objective of this study is to find the practical labour productivity in aluminium formwork system and the factors affecting the labour productivity. For this, research is performed on Purva Silversands project, Pune, Maharashtra (Residential Project). Labour productivity and its variations could generate a greater impact on the project economy and project duration. Low productivity can decrease profitability and increases construction cost. This case study shows that the actual productivity observed is less than the target productivity in some of the months, the reasons for variation in target and actual productivity is examined and the factors that hamper the productivity mostly are natural (rain), improper management and any breakdown of machinery. Whereas, the maximum productivity achieved in a month is 10.36 sqm per man per day.
\end{abstract}

Keywords: Labour productivity, Aluminium Formwork, Conventional Formwork, Factor affecting labour productivity, Mivan.

\section{INTRODUCTION}

\subsection{General:}

The demand for houses in India is huge due to increase in the rate of urbanization so to mitigate the shortage of houses, Pradhan Mantri Awas Yojana (Urban) Mission launched on 25th June 2015 which intends to provide housing for all in urban areas by year 2022.

Manuscript received on October 08, 2021.

Revised Manuscript received on October 11, 2021.

Manuscript published on October 30, 2021.

* Correspondence Author

Raju Narwade, Department of Civil Engineering, HOC College of Engineeringand Technology, Rasayani, Panvel, (Maharashtra), India.

Karthik Nagarajan, Department of Civil Engineering, Pillai HOC College of Engineering and Technology, Rasayani, Panvel, (Maharashtra), India.

Rajnish Singh", Department of Civil Engineering, Pillai HOC College of Engineering and Technology, Rasayani, Panvel, (Maharashtra), India.

(c) The Authors. Published by Lattice Science Publication (LSP). This is an open access article under the CC BY-NC-ND license (http://creativecommons.org/licenses/by-nc-nd/4.0/)
The Mission provides Central Assistance to the implementing agencies through States/Union Territories (UTs) and Central Nodal Agencies (CNAs) for providing houses to all eligible families/ beneficiaries against the validated demand for houses for about $1.12 \mathrm{cr}$. As per PMAY(U) guidelines, the size of a house for Economically Weaker Section (EWS) could be upto 30 sq. mt. carpet area, however States/UTs have the flexibility to enhance the size of houses in consultation and approval of the Ministry(pmaymis.gov.in). So to fulfil the vast and speedy construction demand the productivity is the key factor to attain and keep up the client satisfaction, attract Investment and contribute in making the nation economically successful. By making appropriate use of the available resources such as, material, labour management and capital and increasing efficiency, the productivity can be increased. Since labours contribute to the success of almost all the aspects of the construction project, labour productivity stands as a primary measuring tool. labour productivity has a direct impact on formwork technology. Aluminium formwork is being widely used these days in mass housing projects. Considering the economic benefits of aluminium system formwork and a step towards technological advancement, it is very necessary to have a practical analysis of labour productivity in aluminium formwork construction.

1.1 Significance of Aluminium system formwork with respect to labour productivity:

When it comes to achieving better labour productivity in low-cost housing projects, the importance of the role played by Aluminium system formwork cannot be ignored. Conventional material used to fulfil housing projects being a slow process cannot keep up with the current demands. And this is where the advanced aluminium system formwork steps in because it can keep up with the pace to fulfil the demands. Apart from this, it is fairly simple and easily adoptable for mass construction of houses. It maintains the total quality of work with a methodology that is well defined and can enhance the productivity of labours. But the same cannot be said about the application of this type of formwork in construction of high-rise structures as lack of proper planning can make achieving productivity advantage unsuccessful. Therefore, analysis of labour productivity in aluminium formwork is obligatory to have more realistic planning to mitigate any delay in the project due to labour productivity. 


\section{Analysis of Labour Productivity and Determining the Parameters Which Affects it in Aluminium Formwork System}

\subsection{Construction Labour Productivity:}

Improving labour productivity is the top most priority of any profit-oriented company. The labour productivity in the construction industry can be identified as the physical progress achieved per unit of time period.as seen in equation

(i): $\mathbf{L P}=\frac{\left(\frac{\mathbf{E S Q _ { m }}}{\mathrm{ALS} \mathbf{m}_{\mathbf{m}}}\right)}{\mathbf{N} d_{\mathbf{m}}}$

Where;

$\mathrm{LP}=$ Labour productivity

$\mathrm{ESQ}_{\mathrm{m}}=$ Executed shuttering Quantity in a month

$\mathrm{ALS}_{\mathrm{m}}=$ Average labour strength in a month

$\mathrm{Nd}_{\mathrm{m}}=$ No of working days in a month.

To maintain the site labour productivity, aluminium system formwork can be considered a great approach due to its many benefits, mainly economic and technological. So, it is very necessary to have a practical analysis of labour productivity in aluminium formwork construction.

\subsection{Factors affecting the Labour Productivity:}

Productivity is not affected by a single factor, but set of factors, such as poor management or design errors, economic, labour, material, technological, environmental, administrative, organization related factors etc. that are interrelated to each other and influences the final result. Hence, it becomes necessary to conduct an evaluation of the factors affecting the productivity of labour.

\section{LITERATURE REVIEW}

Vijay. A. S, et al. (2019), concluded that, aluminium formwork system not only saves the time but also saves the money. For determining this, the author used line of balance technique to compare conventional formwork system and aluminium formwork system for multi storey building.

V. Aditya, et al. (2018), carried out a study which states that suitable formwork system is a crucial factor for completion of the project within time. The project includes detailed analysis on duration and cost estimation of a building constructed under PMAY scheme by aluminium and conventional formwork technology. The activity time and quantity calculations of the building unit is determined. Comparison is done based on cost and duration of both technology and their advantages and limitations are discussed. It is analyzed that cost of construction is $18.4 \%$ lesser in aluminium formwork than conventional formwork. The duration of project is lesser than 38days in aluminum formwork. This formwork is most suitable for mass housing project due to its minimal construction cost and comparatively lesser construction time. Renuka S. H, et al. (2017), performed a study to compare different types of formwork systems on the basis of Cost and Time parameters. After evaluating, the author concluded that, Aluminium formwork is Cost effective in comparison with Conventional Formwork. Aluminium formwork is perfect for use in the constructions, where Time effective formwork is required. Tunnel Formwork is the most cost \& time effective formwork among Conventional, Aluminum \& Tunnel Formwork. Aluminium shuttering is preferred if the number of repetitions are more for residential projects, as it saves the cost \& time of shuttering. R. Thiyagarajan, et al. (2017), undertook a study to present about the existing formwork system used in mass housing construction in Tamil nadu and from the results it is analyzed that floor cycle will be 7 to 10 days when the aluminium formwork used in typical floors, and hence the project duration will be reduced by 35 to $40 \%$. At the same time, there will not be any additional activities such as block work and plastering, which further reduces the overall project duration. The Aluminium Formwork System can achieve not only faster rate of construction but can also bring down the structural cost by 20 to 25 percent over the conventional method with lesser labour inputs.

P.V. Praneeth, et al. (2017), the study consists of questionnaire survey to find out advantages and disadvantages of various types of formwork. The questioners were conducted in 22. Major companies like L\&T, SPRE, Ramky, GDCL, NCC etc. In regions like Bombay, Hyderabad, Chennai, Bangalore, and Pune to compare parameters like cost, quality, safety, cycle time etc. Based on study it is observed the Cost adopted for MIVAN formwork is highest among the all-formwork systems this is because of use of aluminum in making of formwork even though cost of MIVAN is high due to higher number of repetitions the overall cost reduces which makes it favorable in repetitive kind of works. MIVAN gives highest Number of repetitions compared with conventional formwork. Faster construction can be achieved with MIVAN formwork as cycle time of MIVAN is less compared to conventional formwork. As per safety management MIVAN is the best in the industry compared with the others Form work systems. Changes can be easily accommodated for conventional when compared with MIVAN. Because MIVAN formwork is already customized and standardized. Amol S. Deshmukh, et al. (2016), the paper focuses on detailed comparison between tunnel and aluminium formwork. For that caste study is done on Rohan Abhilasha Wagholi Project in Pune. The paper concludes that the initial cost aluminium formwork is about Rs. 11000 /sqm, whereas it is very high for tunnel formwork i.e around Rs.22000/sqm. Accuracy is better in tunnel form construction than aluminium formwork construction. Design changes/ design flexibility is easily possible in aluminium. whereas it is very less in tunnel formwork. As Steel is stronger than aluminium, tunnel formwork can be reused more than 500 times and aluminum formwork can be used around 150 times. Skilled staff as well as skilled labours are required in tunnel form system than aluminium form system. GANAR A. S, et al. (2015), published a paper that contains cost and duration analysis of a building constructed by MIVAN formwork building and Conventional formwork building The buildings are of $\mathrm{G}+12$ floors and area of both the buildings are 772 Sqm with $2.95 \mathrm{~m}$ as the height of each floor.The analysis focuses on comparision of both the buildings with respect to cost and duration aspect. Nazul Azam Haron, et al. (2005), the paper outlines the building cost comparison between conventional and industrialised building system in Malaysian construction industry.

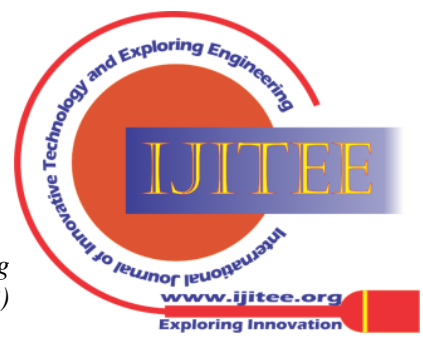


The data were collected through questionnaire survey and case study, which consisting of institutional buildings. Through the statistical test't-test' it is shown that there is a significant difference in cost saving for the conventional system as compared to the formwork system. Pranav Andhyal et al. (2021), have provided a concept of \%D CAD which helps in the billing of the various material estimate parameters such as structural and formwork, etc. Arya Vijayan et al. (2019), research focuses on Internet of thing (IoT) which can be applied in real-time monitoring of appliances which in future can be applied for formworks, etc. Biradar Shilpa et al. (2019), a recent study carried out by the author on Ewaste is emphasized in this research stating that may be in future for scaffolding, formworks etc new waste products which can be recycled can be used. Mahesh S. Singh et al. (2019), in this thesis the author has done a deep analysis of labor productivity which has a direct impact on material management. Pallavi Patil et al. (2019), this research emphasis on a recent concept termed as RMMM which is majorly used for resource management for Use Zoning, Using Topographical Data: Optimizing Vacant Space for Urbanization at Akole Taluka, Maharashtra, India. Sunilkumar Patel et al. (2017), when aluminum formwork system is considered, a major focus moves towards material management and hence in this research the author has tried to work on blue roof system using material management in loob so as to make it more reliable and sustainable. Karthik Nagarajan et al. (2016), in G+10 or more storied building the concepts of scaffolding and formworks plays a vital role in the overall cost of the project, hence here in this research the author has calculated the impact of the floors of the structure on its costs of the materials

\section{RESEARCH GAP}

From the above literature review it is observed that there is no standard procedure applied to calculate the practical measure of the site labour and their efficiency, using aluminium formwork system. Comparison between different kinds of formworks with aluminium formwork system has been performed in past few decades, detailed study has been performed between many types of formwork on various aspects like cost, quality, duration but none of research has emphasized on labour productivity in aluminium formwork system. Hence to bridge this gap this research study felt the necessity of determining the labour output to secure maximum efficiency out of this new technology and achieving a value for money. The paper emphasizes on labour productivity in aluminium formwork system and determining the parameters affecting the labour productivity.

\section{OBJECTIVES}

Keeping in mind the future scope of aluminium formwork and after reviewing the available literature on aluminium formwork, this study has been carried out to bridge the gap by trying to achieve the following objectives

1. Analysis of labour productivity in aluminium formwork system. smart cities. Aditya Shatri et al. (2019): "Integrated Land-

2. Determining the factors affecting the labour productivity in aluminum formwork.

3. Comparison of aluminium and conventional formwork.

\section{PROBLEM STATEMENT}

Labour productivity and its variations could generate a greater impact on the project economy and project duration., also labour productivity majorly controls the formwork system. Low productivity can decrease profitability thus in turn increasing the construction costs. When residential construction is taken into consideration, various factors such as labour, material, subcontracted work, and other costs like overheads and profit margins are taken into account which promotes the usage of prefabrication or modular components. It is considered an effective technology to boost the productivity and achieving cost reduction for the housing projects.

\section{METHODOLOGY}

The methodology adopted for the research are described in the form of a flow chart in Figure 1. The chronological activities involved in this study are present in graphical format. The details of the study are elaborated in the subsequent headings.

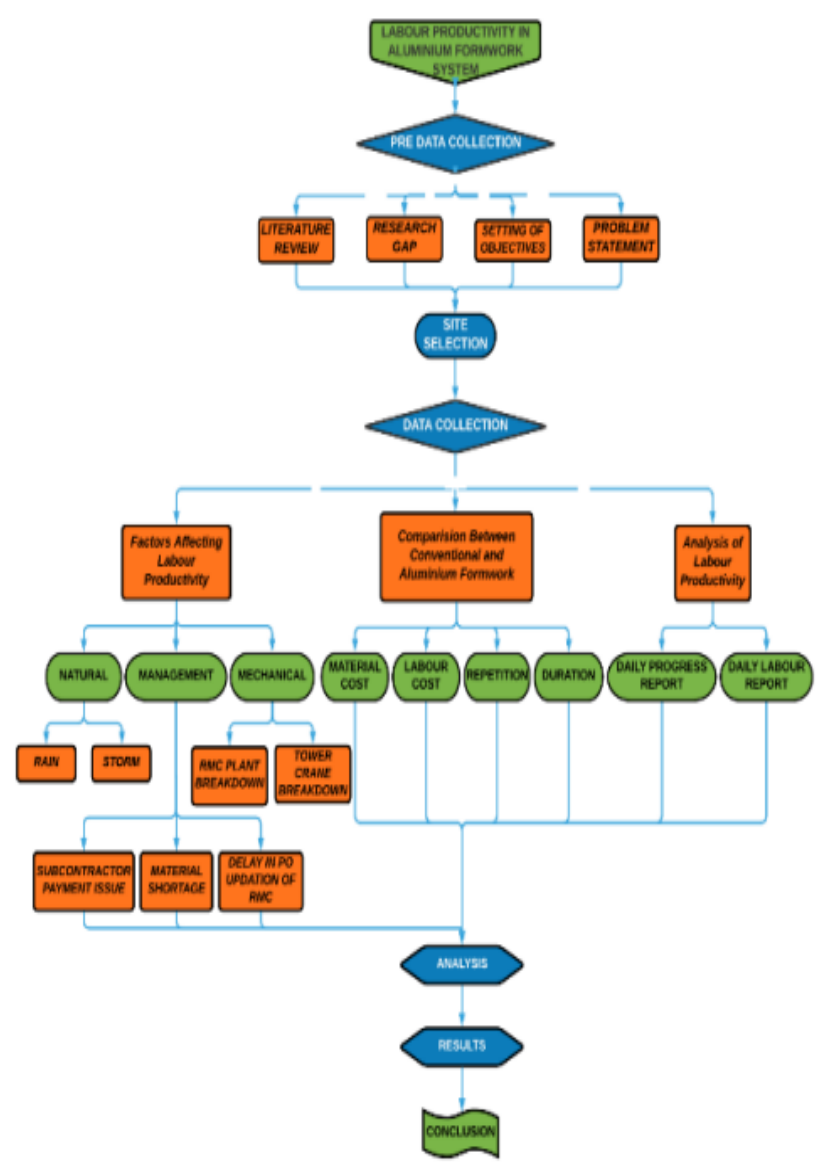

Figure 1: Flow chart showing methodology

Published By:

Blue Eyes Intelligence Engineering and Sciences Publication (BEIESP)

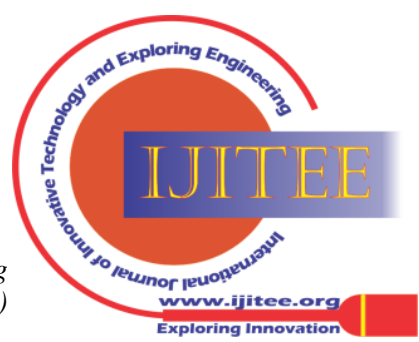




\section{Analysis of Labour Productivity and Determining the Parameters Which Affects it in Aluminium Formwork System}

\section{STUDY AREA}

\subsection{Site Details}

The case study of my project is performed on Purva Silversands project which consists of 13 no's G+22 floors Residential building which is constructed using aluminium formwork and 1 no's G+10 floor Residential building which is constructed using conventional formwork which is located at Keshav Nagar road, Mundhwa, Pune, Maharashtra411036. The latitude and longitude of Mundhwa, Pune is $18.5330^{\circ} \mathrm{N}, 73.9330^{\circ} \mathrm{E}$.

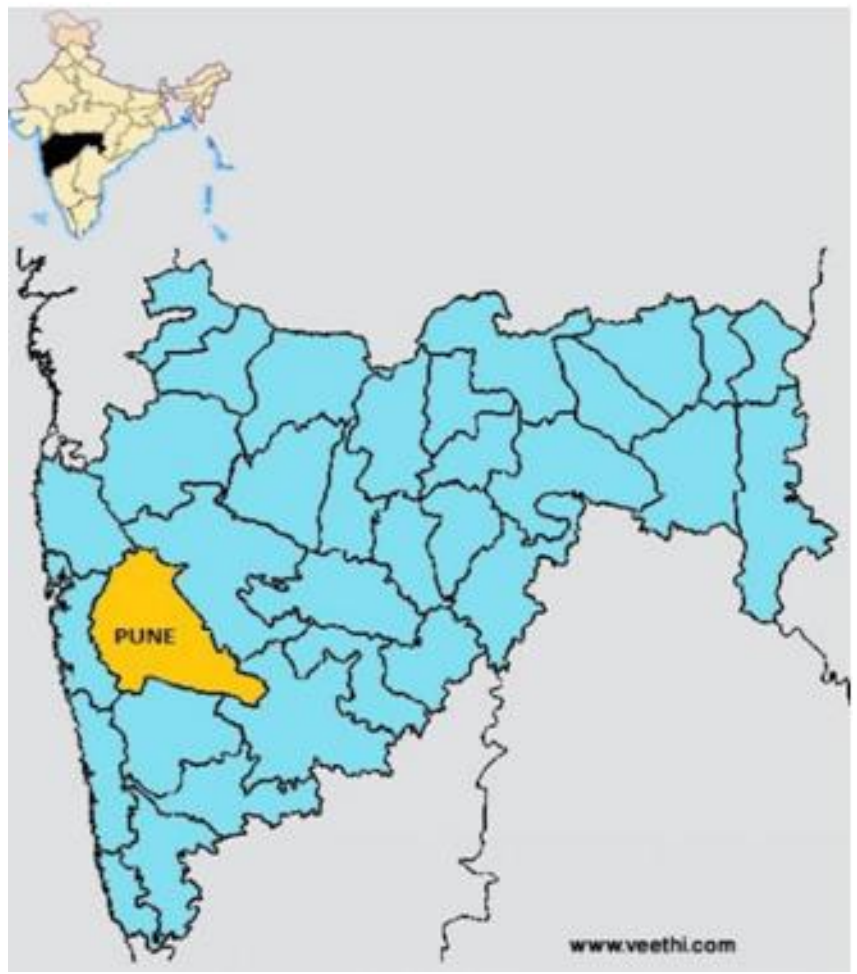

Figure 2: shows the location of Pune in India map.

\subsection{Data Collection:}

\subsubsection{Daily Progress Report (D.P.R.):}

The DPR consist of detailed description of everyday work done quantity of every single activity like shuttering, reinforcement, concreting, plaster, tiling, painting etc. The data of every construction activity are noted according to their respective mode of measurement and recorded in D.P.R on daily basis. It also consists of resources available at site and record of the inventory. Daily work done quantity of every single activity is provided by execution engineer to planning engineer and it is the responsibility of planning engineer to update and maintain D.P.R on daily basis. All the DPR from the starting day of the project till now have been collected.

\subsubsection{Daily Labour Report:}

It consists of detailed number of unskilled labour, carpenter and carpenter helper, fitter and fitter helper, Pipeline gang, mason and mason helper, fabricator, and all labour gang supervisors present on particular date.

\subsubsection{Hindrance Report:}

Hindrance report contains every issue that occurred during execution phase of project which ultimately caused delay in completion of project. This report is also maintained by planning engineer.

\section{ANALYSIS}

The data for study is taken from G+22 and G+10 floor building with aluminium and conventional formwork respectively. The analysis of labour productivity is done on the basis of collected Daily progress report and Daily labour report.Here, work done quantity of every single day of every construction activity is maintained in Daily Progress Report (DPR) and the labour strength of the respective day is also noted in Daily labour report by the concerned planning engineer of the site. To perform the case study, every day shuttering quantity of 8 months (Jan19-Aug19) is noted from the DPR with respect to labour strength of the respective day.Base for analysis:

(i) Labour productivity $=$ (Executed shuttering qty in a month /avg labour strength in a month)/No of working days in a month. All the constraints that affect the productivity is considered. Unit of productivity is square meter per mandays (Sq.m/man-days). Also, a comparison is made between labour productivity of both aluminium formwork and conventional formwork.

\section{RESULTS AND DISCUSSIONS}

After going through all the available resources for this report, thorough calculations combined with case study helped us to find out actual labour productivity in 8 months duration (Jan19-Aug19) in aluminium formwork system. Following below is the real statistics of every month from Jan19 to Aug 19. It consists of every single month executed shuttering quantity in aluminium formwork system along with each month average labour strength present to execute the same. It is observed that out of the 8 months maximum shuttering quantity was executed in April 2019 and the maximum labour strength is observed in August 2019. After getting each month shuttering quantity and each month average labour strength it is analysed that even though the maximum labour strength is in the month of Aug19 the least productivity is achieved in the same month and the maximum productivity is achieved in the month of April 2019.

Table no.1 Shows month wise executed shuttering quantity from Jan19 to Aug19: -

\begin{tabular}{|c|c|c|}
\hline Sr No & Month & $\begin{array}{c}\text { Executed } \\
\text { Shuttering qty } \\
\text { (Sqm) }\end{array}$ \\
\hline 1 & Jan-19 & 12915 \\
\hline 2 & Feb-19 & 17519 \\
\hline 3 & Mar-19 & 15261 \\
\hline 4 & Apr-19 & 22926 \\
\hline 5 & May-19 & 18119 \\
\hline 6 & Jun-19 & 12305 \\
\hline 7 & Jul-19 & 12648 \\
\hline 8 & Aug-19 & 14966 \\
\hline
\end{tabular}

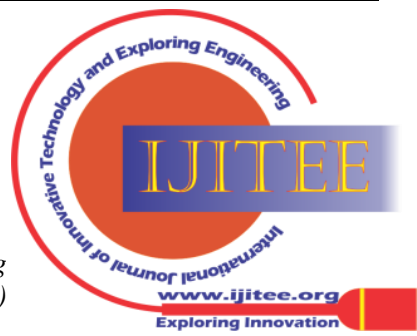




\section{Executed Shuttering qty}

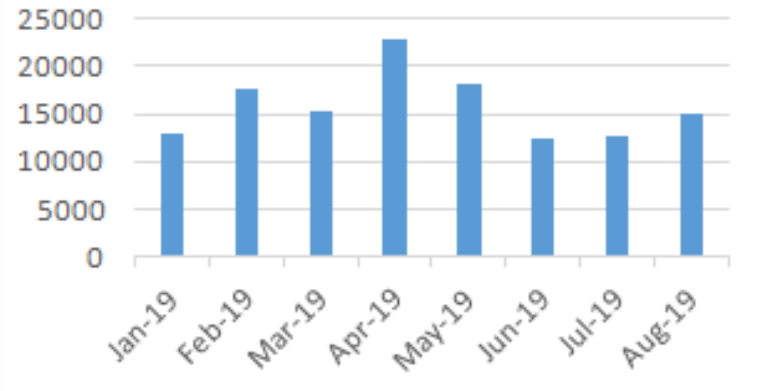

Table no.2 Shows month wise average labour strength from Jan'19 to Aug'19. It is observed that out of the below 8 months maximum labour strength was in August 2019:-

\begin{tabular}{|c|c|c|}
\hline Sr No & Month & $\begin{array}{c}\text { Average } \\
\text { labour } \\
\text { strength } \\
\text { (Nos) }\end{array}$ \\
\hline 1 & Jan-19 & 74 \\
\hline 2 & Feb-19 & 84 \\
\hline 3 & Mar-19 & 79 \\
\hline 4 & Apr-19 & 79 \\
\hline 5 & May-19 & 76 \\
\hline 6 & Jun-19 & 72 \\
\hline 7 & Jul-19 & 89 \\
\hline 8 & Aug-19 & 112 \\
\hline
\end{tabular}

9.3 Labour productivity (L.P): -

L.P = (Executed shuttering qty/avg labour strength $) /$ No of working days in a month.

Table no. 3 shows that the least productivity of labour is observed in the month of august 2019 and the maximum productivity is observed in the month of April 2019.

\begin{tabular}{|c|c|c|c|c|}
\hline Sr No & Month & $\begin{array}{c}\text { Executed } \\
\text { Shuttering } \\
\text { Qty (Sqm) }\end{array}$ & $\begin{array}{c}\text { Average } \\
\text { labour } \\
\text { strength. } \\
\text { (No's) }\end{array}$ & $\begin{array}{c}\text { Labour } \\
\text { productivity } \\
\text { (Sqm/labour) } \\
\text { /month. }\end{array}$ \\
\hline 1 & Jan-19 & 12915 & 74 & 6.23 \\
\hline 2 & Feb-19 & 17519 & 84 & 8.02 \\
\hline 3 & Mar-19 & 15261 & 79 & 6.9 \\
\hline 4 & Apr-19 & 22926 & 79 & 10.36 \\
\hline 5 & May-19 & 18119 & 76 & 8.51 \\
\hline 6 & Jun-19 & 12305 & 72 & 6.1 \\
\hline 7 & Jul-19 & 12648 & 89 & 4.9 \\
\hline 8 & Aug-19 & 14966 & 112 & 4.77 \\
\hline
\end{tabular}

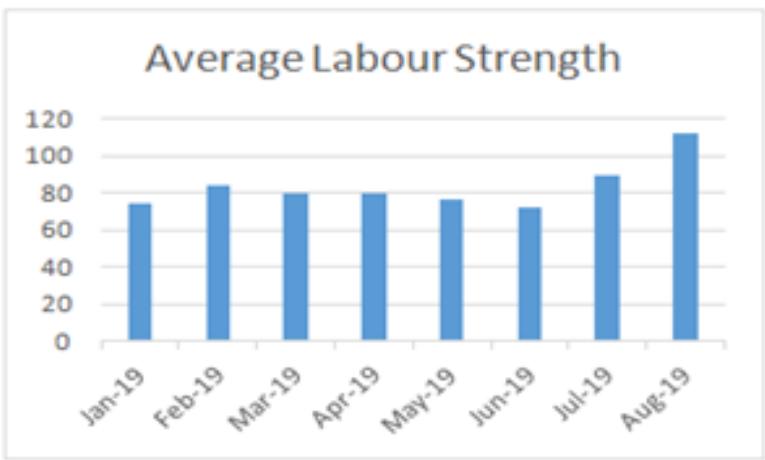

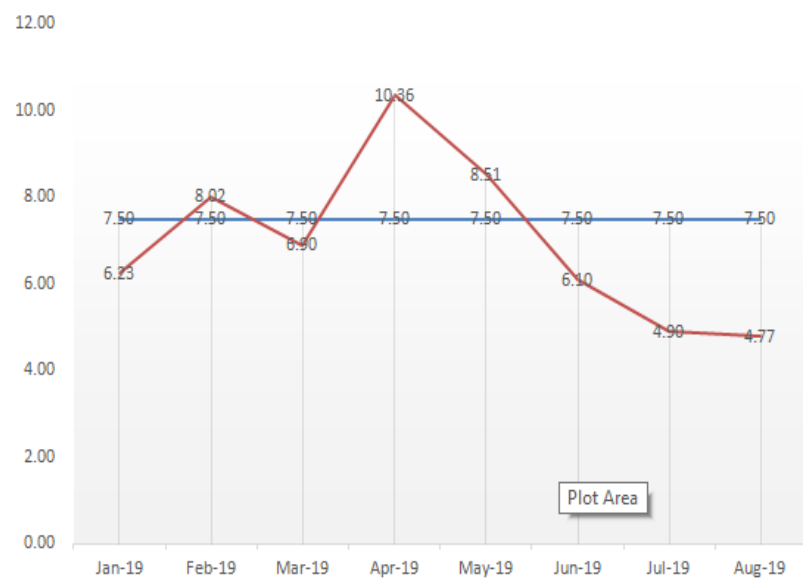

Figure 3: shows that the least productivity of labour is observed in the month of august 2019 and the maximum productivity is observed in the month of April 2019

\subsection{Hindrances affecting the labour Productivity.}

During the study of analysing the labour productivity there were few factors noticed in executing the aluminium formwork shuttering work. Following below are the three factors which influences the labour productivity most in aluminium formwork system.

1. Natural.

2. Management.

3. Mechanical

Natural - Rainfall disturbs the productivity the most and it is clearly seen in the study analysis that the least productivity is observed in the rainy season. Another natural factor is wind speed as the Pune region is at an altitude of 560M (1,840 feet) above sea level, heavy wind speed is observed in monsoon season and because of heavy wind speed the tower cranes are not allowed to work above wind speed of $15 \mathrm{~m} / \mathrm{s}$ which hampers the construction activity abruptly.

Management - Delays in Subcontractor Payment causes many times labour strike which ultimately affected the labour productivity. Many times, concrete delivery was stopped due to delayed in PO (Purchase order) updating of concrete. At numerous instances progress hampered due to non-availability of adequate material like steel, conduiting material, resources (Aggregate, admixtures) in RMC plant. The maximum hampering of work is due to management issues and according to case study the parameter which affects the labour productivity most is due to improper management.

Mechanical - The mechanical issues which influence the labour productivity in aluminium formwork system is due to failure of tower crane and failure of RMC plant and most of the time these are due to ignorance of planned preventive maintenance work.

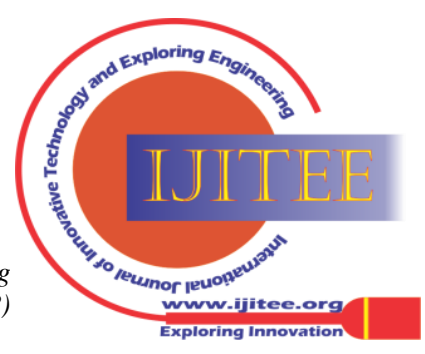




\section{Analysis of Labour Productivity and Determining the Parameters Which Affects it in Aluminium Formwork System}

\subsection{Comparison between Conventional and Aluminium Formwork: -}

A detailed cost comparison is made between conventional and aluminium formwork system and it is noticed that the material cost in conventional formwork system is between Rs.1500 to Rs.2000 per sqm whereas the material cost in aluminium formwork system is between Rs.9,500 to Rs.11,500. The number of repetitions achieved in conventional formwork is about 5 to 7 whereas the repetition in aluminium formwork system is 100-120. Labour cost for fixing and dismantling of formwork for one slab is approx. Rs.4,72,250 whereas Labour cost for fixing and dismantling of formwork for one slab by aluminium formwork system is approx. Rs.2,25,500. Labour cost for completing 25 repetitions by conventional formwork is approx. Rs.1,18,06,250 and Labour cost for completing 25 repetitions by aluminium formwork is approx. Rs.56,37,500.

Table no.4 emphasises on comparison between aluminium and conventional formwork system.

\begin{tabular}{|c|c|c|c|}
\hline \multicolumn{4}{|c|}{ Aluminum formwork V/S Conventional Formwork } \\
\hline $\begin{array}{l}\text { Sr. } \\
\text { No }\end{array}$ & Title & Conventional formwork & Aluminum Formwork \\
\hline 1 & Material cost per Sq.m & 2000 & 10,500 \\
\hline 2 & No of Repetitions can be achieved & 7 & 100 \\
\hline 3 & $\begin{array}{l}\text { Labour cost for fitting and } \\
\text { dismantling of formwork for one slab } \\
\text { (assuming } 45 \text { nos of labours and Rs.500 } \\
\text { per labour per day) }\end{array}$ & $\begin{array}{l}21 \text { man-days } 21 * 450 \\
=4,72,250\end{array}$ & $\begin{array}{l}10 \text { man-days } 10 * 450 \\
=2,25,500\end{array}$ \\
\hline 4 & $\begin{array}{l}\text { labour cost for completing } 25 \\
\text { repetitions. (Assuming } 45 \text { nos of } \\
\text { labours) }\end{array}$ & $1,18,06,250$ & $56,37,500$ \\
\hline 5 & $\begin{array}{l}\text { Time required for } \\
\text { one repetition }\end{array}$ & 18-21 days & 7-10 days \\
\hline
\end{tabular}

\section{CONCLUSION}

There has been enormous growth in labour productivity in the construction industry from the last few years due to advancement in technology. This paper examines the productivity of aluminium formwork system. As per the analysis, it is observed that conventional formwork is useful and cost-effective for small scale construction. However, the significance of this research states that aluminium formwork system is well suited for large scale construction with typical high rise structure.The maximum productivity achieved is $10.36 \mathrm{sqm} / \mathrm{man}$-days. Whereas, the actual productivity was observed less than the target productivity in some months. The reason for variation in target and actual productivity is examined and the factors which hamper the productivity most are Natural (Rain), Improper management and any breakdown of machinery. Comparison is made between Aluminium formwork and Conventional formwork system and it is concluded that Aluminium formwork is more suitable and economical since labour cost is comparatively less and the number of repetitions is more.

\section{REFERENCES}

1. Akshay Gulghane, Nikhil Pitale, Sanket Sanghai (2018): "Time and Cost Optimization of Construction Project Using Mivan Technology". (IJERA), (Aug-2018), ISSN: 2248-9622, Vol. 8, Issue 8 (Part -II), pp 70-74

2. Amol S. Deshmukh, Mr. Manas A. Shalgar (2016): "Study of Tunnel Formwork versus Aluminium Formwork". International Research

3. Arya Vijayan, Karthik Nagarajan,Raju Narwade (2019) : "Real Time Water Leakage Monitoring System Using IoT Based Architecture “ International Journal for Research in Engineering Application \& Management (IJREAM), (Nov-2019), ISSN : 2454-9150, ,Vol-05, Issue-08, pp.24-30

4. Aditya Shatri, Karthik Nagarajan, RajuNarwade (2019): "Integrated Land-Use Zoning, Using Topographical Data: Optimizing Vacant Space for Urbanization at Akole Taluka, Maharashtra, India "International Journal of Advanced Research in Engineering and Technology (IJARET), Volume 10, Issue 1, (Jan-Feb 2019), pp. 188199, IAEME Publication, Article ID: IJARET_10_01_018, Print: 0976-6480 and ISSN Online: 0976-6499

5. Biradar Shilpa, Karthik Nagarajan, Raju Narwade, Gayatri Deshpande (2019): "E-Waste: An Alternative to Partial Replacement of Coarse Aggregate in Concrete ", International Journal of Engineering Research \& Technology (IJERT), (July-2019), ISSN: 2278-0181, Volume 08, Issue 07 (July 2019), pp.993-999

6. Chowdary Mohanlal, Karthik Nagarajan, RajuNarwade (2019): "Applications of 4D GIS Model in Construction Management", International Journal of Innovative Technology and Exploring Engineering (IJITEE), (July-2019), ISSN: 2278-3075, Volume-8 Issue-9, July 2019, pp.2597-2608.

7. Chhaya Zende, Karthik Nagarajan, RajuNarwade (2019) "Manufacturing Techniques of Sustainable Recyclable Formwork By A Smart Material Waste Composite Material (WCM) for Infrastructural Projects of Future Cities - A Swachh Bharat Abhiyan Initiative “ , International Journal of Management, Technology And Engineering (IJMTE) , (June-2019), ISSN NO : 2249-7455 ,Vol:9, Issue:6, pp.666-671

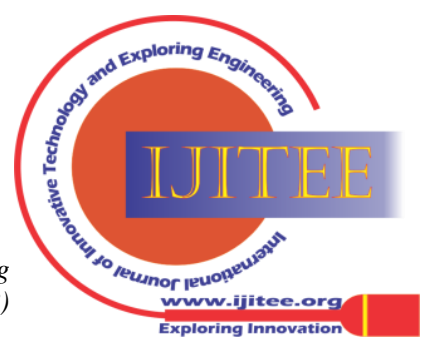


8. Ganar A. S, Patil S. D (2015): "Comparative analysis on cost and duration of MIVAN formwork building and Conventional Formwork building". International Journal on Recent and Innovation Trends in Computing and Communication, (Dec-2015), ISSN: 2321-8169. Volume:3 Issue: 1.

9. Karthik Nagarajan and Shrikant Charhate (2016): "Smart Moda Analysis of Multi-storeyed Building Considering the Effect of Infill Walls.", International Journal of Global Technology Initiatives (IJGTI), (March 2016), Vol:5, Issue:1, p-ISSN: 2277-6591, e-ISSN: 2320-1207 pp.C20-C27.

10. Mahesh S. Singh, Karthik Nagarajan, Raju Narwade, Tejaswini D. N. (2019): "Factors affecting the labor productivity of brickwork and analyzing them using RII method "International Journal of Advanced Technology and Engineering Exploration, (IJATEE), (May-2019), ISSN (Print): 2394-5443 ISSN (Online): 2394-7454, Vol-06, Issue54, pp.143-151.

11. Nazul Azam Haron, Ir. Salihuddin Hassim, Mohd. Razali Abd. Kadir Conventional and Formwork System: A case study of Four-storey School Buildings in Malaysia". American Journal of Applied Science. ISSN 1546-9239.

12. PV. Praneeth, SS. Asadi (2017): “A COMPARATIVE STUDY FOR EVALUATION OF DIFFERENT FORM WORK SYSTEMS UTILIZATION IN CONSTRUCTION PROJECTS”. International Journal of Mechanical Engineering and Technology, (Nov-2017), ISSN Print: 0976-6340.Volume 8, Issue 11.

13. Pranav Andhyal, Karthik Nagarajan, Raju Narwade (2021) International Journal of Innovative Technology and Exploring Engineering (IJITEE), (Feb-2021), ISSN: 2278-3075, Volume-10 Issue-4, Feb 2021, pp.2597-2608.

14. Pallavi Patil, Karthik Nagarajan, Raju Narwade (2019): "Resource Management of Infrastructural Project for Future Cities: A Re Modified Minimum Moment method "International Journal of Management, Technology and Engineering (IJMTE), (Feb-2019), ISSN NO: 2249-7455, Vol:9, Issue:2, pp.1094-1099.

15. R. Thiyagarajan V, Panneerselvam, K. Nagamani (2017) "Aluminium formwork system using in high-rise buildings construction". International Journal of Advanced Research in Engineering and Technology, (Nov-Dec 2017), ISSN Print: 09766480. Volume 8, Issue 6 .

16. Renuka S. Hangarge, Prof. Ashish P. Waghmare (2017): "Cost and Time estimation for Conventional, Aluminium \& Tunnel Formwork". International Research Journal of Engineering and Technology (IRJET). ISSN: 2395-0072, (July-2017), Volume: 04 Issue: 07.

17. Shrenik Shah, Karthik Nagarajan, Raju Narwade and (2020) "Assessment of Urban Utilities for Mumbai City Using 3d Modeling Techniques", International Journal of Civil Engineering and Technology (IJCIET), (May 2020), ISSN Print: 0976-6308 and ISSN Online: 0976-6316, Volume-11, Issue-5.

18. Sunilkumar Patel, Karthik Nagarajan, RajuNarwade (2017) "Sustainable Smart Blue Roof Network System with the application of Geographic Information System (GIS) “, International Journal of Engineering Research in Mechanical and Civil Engineering (IJERMCE), (March 2017), Vol:2, Issue:3, pp.423-428, ISSN (Online) 2456-1290.

19. Vijay Anil Sonawne, Harshita Ambre (2019): "Comparative Analysis of Aluminium Formwork Building and Conventional Formwork Building based on Duration by using Line of Balance (LOB) Technique". International Research Journal of Engineering and Technology (IRJET), (May-2018), ISSN: 2395-0056, ISSN: 23950072. Volume: 06 Issue: 05. formwork technology in affordable housing scheme based on cost and duration". International Journal of Advanced Science and Engineering Research. ISSN: 2455-9288. Volume: 3, Issue: 1.

WEBSITES:

pmaymis.gov.in

\section{AUTHORS PROFILE}

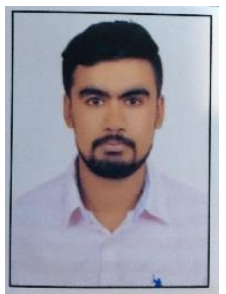

Name: Rajnish Singh

Department: Civil Engineering.

Email:rajsingh6767@gmail.com

Address: A-301, sportslife CHS, sec-01, Kalamboli

College Name: Pillai HOC College of Engineering

and Technology, Rasayani, Panvel,

Maharashtra.Mobile $\quad$ No. 9167906767

Education:M.E. (Pursuing): Construction

Engineering and Management. Mumbai and Mohd Saleh Jaafar (2005): "Building Cost Comparision between "Applications of 5D CAD for Billing in Construction using GIS “

20. V. Aaditya, Dr.S.Anandakumar (2018): "Scope of aluminium

UniversityB.E. 2017: Pune University in Civil Engineering . Area of Interest Construction Planner / Planning Engineer, Assistant Project Manager, Site Engineer, Billing Engineer, QC, BBS.

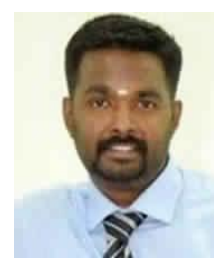

Name: Karthik Nagarajan.

Department: Faculty of Civil Engineering.

Email: knagarajan@mes.ac.in

College Name: Pillai HOC College of Engineeringand Technology, Rasayani, Panvel, Maharashtra.

Mobile No. 9819420975

Education:

Ph.D. (Pursuing): Mumbai University in Civil Engineerin ,M.E. 2009: Mumbai University in Civil Engineering

B.E. 2002: Mumbai University in Civil Engineering Research and Consultancy Application of Remote Sensing and GIS in Water Resources

Courses Civil Engineering: Structural Engineering, Water Resources, RemoteSensing and GIS

\section{Important Publication}

1. Karthik Nagarajan and Shrikant Charhate (2016): "Smart Moda Analysis of Multistoried Building Considering the Effect of Infill Walls", International Journal of Global Technology Initiatives (IJGTI) 5.1 (2016), Vol: 5 Issue:1, pp. C20-C27

http://ijgti.org.in/index.php/ijgti/article/view/361

2. Karthik Nagarajan, Raju Narwade and Sunilkumar Patel (2017) "Sustainable Smart Blue Roof Network System with application of Geographic Information System (GIS)", International Journal of Engineering Research in Mechanical and Civil Engineering (IJERMCE),(2017) Vol: 2, Issue: 3, pp. 423-428 http://technoarete.org/common_abstract/pdf/IJERMCE/v4/i3/Ext 19824 pd

3. Karthik Nagarajan, Mihir Patil Hande, Siddhesh Satere, Pulkit Gupta (2017) : "Rehabilitation and Cost Effective house for Sustainable Rural Development - A Case Study of Landslide affected Dasgaon village in Maharashtra" International Journal of Engineering Research in Mechanical and Civil Engineering (IJERMCE), (2017) Vol 2, Issue 4, pp. 25-31

http://ijermce.com/abstract.php?id=9587

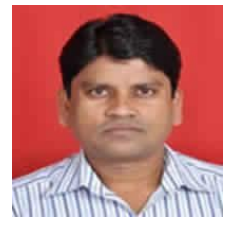

\section{Name: Raju Narwade}

Department: Faculty of Civil

Engineering. Email:

rnarwade@mes.ac.in

College Name: Pillai HOC College of Engineering and Technology, Rasayani, Panvel, Maharashtra.

Mobile No. 8108202122Education:

Ph.D. (Pursuing): Mumbai University

M.E. 2011: Mumbai University in Structural Engineering

B.E. 1999: Shri Guru Gobind Singhaji College of Engineering and Technology, Nanded (MS)

Research and Consultancy

Minor research Project Grant from University of Mumbai (2014)

Minor research Project Grant from University of Mumbai (2017)

ISRO Sponsored Research Work at Indian Institute of Remote Sensing,Deharadun (2018)

Research work at Central Building Research Institute, Rorkee (Uttarakhand) (1996)

Courses

UG Level: 1. Engineering Mechanics 2. Strength of Materials 3. Structural Analysis-I 4. Structural Analysis-II 5. Limit State Method Reinforced Concrete Structure 6. Reinforced Concrete Repair and Maintenance

PG Level: 1.Repairs, Rehabilitation and Retrofitting of Structure 2. Advanced Construction Technology 3.Energy Conservation Techniques in Building Construction 4.Disaster Management and Mitigation Measures 5. Total Quality Management in Construction 5.Remote Sensing and Geographical Information System

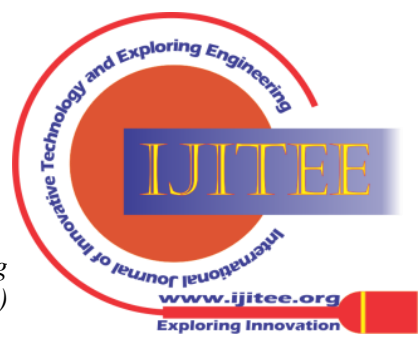




\section{Analysis of Labour Productivity and Determining the Parameters Which Affects it in Aluminium Formwork System}

Important Publications

1. Pravin Shahi and Raju Narwade (2018)" Optimization Measures and Techniques of Structural Assessment- A Non Destructive Test Approach" International Journal of Civil Engineering and Technology, Volume 9,
Issue 3,March 2018,
pp. 906-913,

http://www.iaeme.com/MasterAdmin/Journal_uploads/IJCIET/VOL UM E 9 ISSUE 3/IJCIET 09 03 090.pdf

2. Prathamesh Brid and Raju Narwade (2017) "Fuzzy AHP-Vikor Method for Decision Making for Residential Project" International Journal of Innovative Research in Science, Engineering and Technology, Vol. 6, Issue8,August 2017.

(https://www.ijirset.com/upload/2017/august/208 \%20prathamesh_paar .pdf)

3. Prathamesh A. Brid and Raju Narwade (2017), "Fuzzy logic use for Decision-making in Construction Industry" published in International Journal on Recent and InnovationTrends in Computing and Communication (IJRITCC) Vol.5

Issue5,May2017.(www.ijritcc.org/download/browse/Volume 5.../149647 6407 03- 06-2017.pdf)

4. Sunilkumar Patel, Karthik Nagarajan and Raju Narwade" Sustainable Smart Blue Roof Network System with application of Geographic Information System (GIS)'International

Journal of Engineering Research in Mechanical and Civil Engineering, Vol. 2(3)

https://www.researchgate.net/publication/318570727_Sustainable_Smart Blue_Roof_Network

System with application of Geographic Information System GIS 1

5. Pradnya Mawale and Raju Narwade "Traffic Study and Analysis of Project Road (SH-93) Using Pavement Management System" International Journal of Current Engineering and Technology, Vol. No $7(1)$.

(https://www.google.co.in/search?q=Traffic+Study+and+Analysis+of + P roject+Road+(SH-93)

6. Suhas G. Awari, Raju Narwade and Manisha Jamgade "Analysis for cause identification for delay in building construction industry" International journal of Modern Trends in Engineering and Research, ISSN No 2393-8161

(https://www.ijmter.com/papers/volume-3/issue-10/analysis-for-cause-id entification-for-delay-in-building-construction-industry.pdf) Awards and Recognitions

- Recognized Post Graduate Guide, University of Mumbai

- Recognized Post Graduate Teacher, Pune University

- Joint Chief Conductor of examination, University of Mumbai (2012)

- Member of panel for examination for Maharashtra Public Service Commission (2004)

- Engineering Mechanics subject expert in Sasmira Institute of Man- Made Textile, Worli Mumbai (2000)

- Selected for Govt. and ISRO Sponsored Training Programme at Indian Institute of Remote Sensing, Dehradun (2018)

- Syllabus Revision Committee Member for Concrete Technology, Structural Analysis-I and II Courses of UG in Civil EngineeringUniversity of Mumbai.

- Syllabus Revision Committee Member for Total Quality Management in Construction and Construction safety, Energy Conservation Techniques in Building Construction Courses of PG in Civil Engineering-University of Mumbai

- Life Member of ISTE, ISRS, ISH, ASTR and IWWA

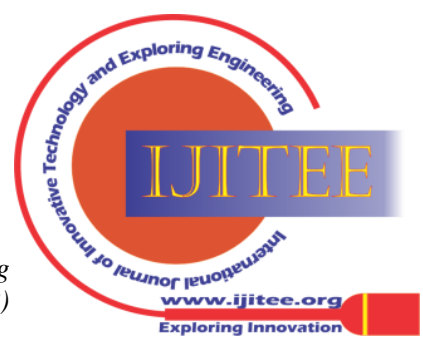

